\title{
The Phenomenon of Believing without Belonging among Slovak Youth (What does a youth who does not identify with any religion believe in? $)^{1}$
}

\author{
Ondrej Štefaňak \\ Constantine the Philosopher University in Nitra
}

\begin{abstract}
In various societies, a certain percentage of people do not identify with any church or religious group. In Slovakia, according to the last census, it is about $15.0 \%$. P. M. Zulehner argues that attempts are being made to portray this type of people as 'unbelievers', but some sociologists might argue about what 'unbelief' actually means, as it is defined only in the categories of rejection of the official religious organizations. The type of 'unbelievers' refers to people who do not accept the official models of religiosity and who create a new one - their own interpretations of life and the world. In the outlined context, the presented sociological study seeks to approach the phenomenon of believing without belonging (concept of G. Davie) among Slovak youth. The author asks and tries to answer the question. What does a youth who does not identify with any religion believe in? The conclusions rely mainly on research into the religiosity of youth in the regions of Spiš, Liptov and Orava, in which around $10.0 \%$ of young people do not identify with any church or religious group. The study focuses mainly on less official, respectively, formal religious dimensions - e.g. religious experience, acceptance of religious doctrine, acceptance of religious morality, etc.
\end{abstract}

\section{Keywords}

Religious faith; Religious affiliation; Slovak youth; Believing without belonging.

\section{Contact Address}

Assoc. Prof. Ondrej Štefaňak, PhD., Department of Sociology, Faculty of Philosophy, Constantine the Philosopher University in Nitra, ostefanak@ukf.sk

\section{Introduction}

Up until quite recently, there have been a prevailing opinion within the context of sociology of religion that at the times of social modernization religion and religiousness gradually

${ }^{1}$ This work was supported by the Slovak Research and Development Agency under contract No. APVV-17-0158. 
lose their meaning. Many contemporary sociologists of religion instead point to various trends in religiousness and spirituality which not only reveal gradual secularization but at the same time also pluralisation, privatization, de-secularization, de-privatization, renewed spirituality and evangelization. There are ongoing discussions between those still referring to the theory of secularization and those who are searching for new explanations of religious changes in the world today. Various theories that have been created within the sociology of religion are sometimes presented as competitors, but in fact they do not exclude one another and are mutually complementary. For a deeper understanding of numerous changes in the context of the religion of our contemporary world, there is a need to find connections between paradigms. Modern societies have a tendency to give way to multiple types of religious transformation that have many forms and directions. There is not even one universal scenario, nor there is one universal theory existing in the sociology of religion. ${ }^{2}$

Modern sociology provides several theories or paradigms that are based upon empirical research. Historically first is 'the classical' theory of secularization. There also exist several more which are not dealt with in all that much detail here, for example, the theory of religious pluralism, the theory of religious individualism, the theory of scattered religiousness, the theory of religious fundamentalism, the theory of de-secularization, etc. We can also understand the above-mentioned theories or paradigms as certain scenarios or models for religious changes in the world at present. It is also important to remember the fact that sociology of religion is a discipline that adheres to the principle of neutrality - in other words the sociologists of religion observe and explain religious changes but do not speak about religious development or decline. ${ }^{3}$

Each of the paradigms that have been mentioned or not mentioned above enriches our knowledge of religiousness and its transformation within the context of sociology of religion. There are also several statements from socio-religious circles that say a great deal about changes on the background of the religious scene in the world today. The term "belonging without believing" is used, for example, by D. Hervieu-Léger to name those people who formally belong to a certain religious organization, even declaring this allegiance, but in reality not agreeing with all its teaching. ${ }^{4}$ There is also the statement of G. Davie "believing without belonging" to identify those who in reality accept certain truths of faith of a specific religious organization although they formally do not belong to it or do not identify with it. ${ }^{5}$ The latter statement, which is the object of interest for this article, is specifically its verification in the context of the young people in Slovakia. The whole text consists of one shorter and one longer part: 1 . Theoretical and methodological assumptions, 2. Slovak youth and the phenomenon of believing without belonging.

\footnotetext{
2 Janusz Mariański, Religia v społeczeństwie ponowoczesnym (Warszawa: Ofycina Naukowa, 2010), 9-13.

${ }^{3}$ Janusz Mariański, Emigracja z Kościota. Religijność mtodzieży polskiej w warunkach zmian spotecznych (Lublin: Wydawnictwo KUL, 2008), 13-35.

${ }^{4}$ Danièle Hervieu-Léger, Religia jako pamięć (Kraków: NOMOS, 1999), 219-220.

${ }^{5}$ Grace Davie, "Od obowiązku do konsumpcji: modele religijności w Europie Północnej na początku XXI w.", Wokót wspótczesności, no. 2 (2004): 14-30.
} 


\section{Theoretical and methodological assumptions}

The main focus (point of research) in this presented study is an analysis of the phenomenon of faith without affiliation among young people in Slovakia. In other words - it looks for an answer to the following question. To what extent and what do young people who do not associate with any religion, church or denomination believe in? According to numerous sociologists of religion, we face more and more so-called 'scattered religion'. By using this term they try to underline the fact that religion or religious values and ideas do not disappear but change their position in society. Specifically they claim that these values are less and less 'concentrated' in religious organizations, denominations, churches, shrines or church buildings and are increasingly widely 'scattered' all around and therefore it is possible to find them in various spheres of life where we would hardly expect to see them. ${ }^{6}$

Other sociologists of religion point out that 'ecclesiastical indifference' is not the same as 'religious indifference'. In their view, many believers are simply disappointed with religious institutions (for example hiding, not solving or insufficient solving of burning issues) and therefore they gradually become indifferent towards them. This does not mean, however, that they are indifferent in relation to a religion, religious faith, respectively to God. ${ }^{7}$ These presented theses, as well as other theories and statements in the sociology of religion, have to be constantly verified with the help of empirical research. In the outlined context of this article, I would like to introduce several interesting sociological analyses from which we can step by step obtain a real picture of the religious values, attitudes and behaviour of the young generation in Slovakia that does not identify itself with any religion, church or religious organization.

From those two above mentioned phenomenons ('belonging without believing' and 'believing without belonging') it is clearly easier to analyse the first of them. Affiliation without faith can be simply described, for example, when we measure what percentage of Christians do not accept the truths of the faith for Christianity, do not take part in Christian religious acts, do not adopt Christian moral norms, etc. ${ }^{8}$ Faith without affiliation is harder to analyse. It touches people who do not identify themselves with any denominational institution. According to the last census, there are approximately $15 \%$ of them in Slovakia. P. M. Zulehner has taken notice of the fact that there are ongoing efforts to present this type of people as 'atheists', however very few sociologists can say what this 'atheism' in fact means, as it is defined only in the categories of rejecting official religious structures. The type of 'atheists' category deals with people who do not accept official models of

\footnotetext{
${ }^{6}$ Robert Cipriani, Diffused Religion: Beyond Secularization (London: Palgrave Macmillan, 2017).

${ }^{7}$ Egon Spiegel, "Specter of Secularization. Against the Identification of Ecclesiastical Indifference and Religious Indifference." Lecture from an international scientific conference on the topic of: "Metamorphoses of Religion and Spirituality" (Warsaw - 23 May 2019).

${ }^{8}$ I dealt with this issue in detail within the context of youth in Slovakia in: Ondrej Štefaňak, "Katolícka mládež = katolícka viera?” in Porta fidei - Rok viery, ed. František Dlugoš (Ružomberok: VERBUM, 2013), 165-196.
} 
religiousness and create their own, new interpretations of life and the world. ${ }^{9}$ S. Wróbel and K. Skonieczny, writing about atheism, formulate three interesting questions. What is atheism, especially in its philosophical form, which has been dubbed the "atheism of the concept"? Are we living in a post-atheistic age and, if so, what does this entail? What form of atheism should we remain faithful to today? ${ }^{10}$

We can also add that when we speak about possible changes concerning the size of the group of people without religious affiliation in Slovakia, their indicator is increasing quite slowly. According to the latest census (2011), about 76\% of Slovak people claimed an affiliation to various religious organizations $(13.4 \%$ were without any denomination and $10.6 \%$ did not provide any answer). The fact is that $65.8 \%$ of Slovak citizens claimed their affiliation to the Catholic Church, 5.9\% to the Evangelical Lutheran Church, $0.9 \%$ to the Orthodox Church and 3.4\% to other churches or denominational organizations. If we calculate these results 'in election style', which means that we do not take into consideration the votes that were not submitted, there were $85.0 \%$ of believers $(73.6 \%$ Catholics) and $15.0 \%$ of non-believers in Slovakia in 2011 (in 2001: it was $86.6 \%$ of believers and $13.4 \%$ of non-believers; in 1991: $88.1 \%$ of believers and $11.9 \%$ of non-believers). ${ }^{11}$ Although religious affiliation is only one of many other indicators of religiousness that the sociologists of religion take into consideration in their research, It can be said (on the basis of this outline, which is from a methodological perspective completely legitimate) that Slovakia is slowly becoming more secular.

Within the outlined context, our presented sociological study attempts to draw near the phenomenon of faith without affiliation among young people in Slovakia. It asks and attempts to answer the question as to what those people who do not identify with any religion believe in? All the accepted conclusions will be based upon our own empirical research of religiousness among young people in the regions of Spišs, Liptov and Orava that took place in $2006^{12}$ and in $2016^{13}$ using a sample of 629 and 766 respondents. As such, they are trying not to be ideologically burdened but instead sociologically balanced. Within the scope of this research, there are about $10 \%$ of young people who do not identify

\footnotetext{
${ }^{9}$ Paul M. Zulehner, "Religia z wyboru jako dominująca forma społeczna”, in Socjologia religii. Antologia tekstów, ed. Władysław Piwowarski (Kraków: NOMOS, 2003), 383-408.

${ }^{10}$ Szymon Wróbel and Krzysztof Skonieczny, "Introduction to Atheism," in Atheism Revisited, ed. Szymon Wróbel and Krzysztof Skonieczny (Cham: Palgrave Macmillan, 2014) 1-14.

${ }^{11}$ https://slovak.statistics.sk/wps/wcm/connect/54eb0cba-ec99-4549-8a33-5c86eead59c1/Tab_14_ Obyvatelstvo_SR_podla_nabozenskeho_vyznania_scitanie_2011_2001_1991.pdf?MOD=AJPERES\&C VID=knLHnky\&CVID=knLHnky\&CVID=knLHnky\&CVID=knLHnky, adapted 15 October 2020.

${ }^{12}$ It was a questionnaire survey on youth religiousness. The core was a group of young people aged 17-18 in the regions of Spiš, Liptov and Orava. From this basic group - using quota sampling - we selected another preferential group that consisted of 663 young people $(24$ classes from eight state schools and one church school). There were 629 active respondents representing $94.9 \%$ of the preferential group.

${ }^{13}$ It was a questionnaire survey on youth religiousness. The core was a group of A-level young people in the regions of Spiš, Liptov and Orava. From this basic group - using quota sampling - we selected another preferential group that consisted of 708 young people (30 classes from seven state schools and two church schools). There were 677 active respondents representing $95.6 \%$ of the preferential group.
} 
themselves with any church or denominational institution - 62 (2006) and 58 (2016). ${ }^{14}$ The focus of our study will be the views within this category of young people about certain religious, philosophical and respectively ethical questions. It centres on less official or less formal expressions of religiousness, for example, religious experience, acceptance of religious doctrine, acceptance of religious morality, etc. It partially refers to the data from the last three population censuses in Slovakia, thanks to which it is able to give an answer to the following question: to what extent can the size of a group of people without religious affiliation increase or decrease.

\section{Slovak youth and the phenomenon of believing without belonging}

In the following parts of this article, we will introduce various elements of religiousness (religious values, attitudes and types of behaviour) among young people in Slovakia - involved in this research - who do not identify with any religion, church or denominational institution. Thus we will proceed on the background of seven basic parameters of religiousness: general religiousness, practising of religious acts, acceptance of religious doctrine, religious knowledge, religious experience, religious community and acceptance of religious morality. ${ }^{15}$ Special attention will be given to less official, respectively less formal, expressions of religiousness, namely to acceptance of religious doctrine, religious experience and acceptance of religious morality. In order to introduce various elements of religiousness among young people without religious affiliation in a complete and logical way, we will choose from two to four most basic indicators of religious participation from each of the stated parameters of religiousness as required for this analysis.

Before the introduction of the individual indicators of religiousness among young people without religious affiliation, we can briefly say that the majority of this group was more often represented by boys (boys $-65.0 \%$, girls $-35.0 \%$ ), young people from more populated zones (village $-30.3 \%$, town population less than $20,000-16.8 \%$, city population more than $20,000-52.9 \%$ ), respondents from smaller families (one or two children $-58.0 \%$, a family with three children $-29.4 \%$, four children or more $-12.6 \%$ ) and children with poorer results at school (very good $-22.7 \%$, good $-41.2 \%$, average or worse $-36.1 \%$ ). Among the participants of the two studies, a typical representative of a young person without religious affiliation is a boy from a larger city who lives in a smaller family and achieves average, medium level or poorer study results.

\footnotetext{
${ }^{14}$ More methodological information about the two studies can be found in Ondrej Štefaňak, Religiozita mládeže v procese premien (Nitra: Univerzita Konštantína Filozofa v Nitre, 2019), 33-47.

15 Władysław Piwowarski, Socjologia religii (Lublin: Redakcja Wydawnictw KUL, 2000), 58-66.
} 


\section{General religiousness}

On the basis of the acquired empirical results concerning the young generation without religious affiliation, it can be argued that there was a reported higher than zero degree of positive attitude to faith. Around one tenth of these young people (9.2\%), considered themselves to have a deep faith, faith or at least some kind of connection with religious tradition: with a deep faith $-2.5 \%$, with faith $-4.2 \%$, undecided but connected with religious tradition $-2.5 \%$. Somewhat higher indicators of religiousness were reported in the case of the general attitude to religious acts - not closely defined, diverse, etc. The acquired empirical results among young people without religious affiliation indicate that around one seventh of these young people at least occasionally practised some kind of not closely defined religious acts $(17.5 \%)$ : the practice is systematic $-0.8 \%$, the practice is not systematic $-1.7 \%$, the practice is rare $-15.0 \%$.

In the scope of the outlined context, the phenomenon of faith without religious affiliation could cover a range of one tenth to one seventh of young people in Slovakia (being the focus of this research) who do not identify themselves with any specific religion, church or denominational institution and at the same time consider themselves to have faith or at least some connection with religious tradition, respectively at least occasionally practice some kind of not closely defined religious acts. It is important to validate, however, this claim more extensively and in depth on the basis of the following: more specific parameters and indicators of religious participation.

\section{Practising of religious acts}

The basic part of religious parameters is the practice of specific religious acts, for example, participation in church services, active use of prayer or following the act of fasting. It was apparent that among the young generation without religious affiliation the indicator of those who attended the church services at least on special feasts was only $5.8 \%$ (every Sunday $-0.8 \%$, nearly every Sunday $-0.8 \%$, once or twice a month $-1.7 \%$, only on special feasts $-2.5 \%$ ). Although an additional $15.8 \%$ of these young people declared their participation in church services (on the occasion of a wedding, funeral, etc.), this participation should be understood as an expression of family solidarity and not as a sign of religious participation.

Prayer is a general indicator of practising of religious acts which does not concern only the members of various religious denominations but also people without religious affiliation. It is therefore logical that in this case slightly higher indicators of religiousness were reported. On the basis of the acquired empirical results, it is apparent that as many as one quarter of the young people without religious affiliation used prayer at least on an occasional basis $(25.8 \%)$ : every day $-2.5 \%$, once every couple of days $-1.7 \%$, from time to time $-2.5 \%$, only in serious life situations $-5.8 \%$, very rarely $-13.3 \%$. It the case of this presented parameter of religiousness, the phenomenon of faith without religious 
affiliation could cover a range of one fifth or even one quarter of Slovak youth which does not identify with any specific religious denomination and prays either very rarely or only participates occasionally in church services.

\section{Acceptance of religious doctrine}

Within the scope of acceptance of religious doctrine, which can be included among less official or less formal expressions of religiousness, we will present empirical data relating about faith in the existence of some Higher Authority that we can call God, about faith in an afterlife, about faith in reincarnation (further incarnation of souls) and finally about the relationship of people involved in this research into God. It can be stated overall that around one fifth of young people without religious affiliation declared a faith in some Higher Authority that we can call God (20.8\%): definitely believe $-10.0 \%$, somewhat believe $-10.8 \%$. In addition, it is important to say that explicit disbelief (no faith) in God was declared by only half of these young people (50.0\%) - quite a large percentage of them marked the answer 'it's difficult to say' (29.2\%).

In a similar fashion, the general indicator of acceptance of religious doctrine is faith in the afterlife. On the basis of recorded empirical data, we can say that more than one quarter of the young people without religious affiliation presented their faith in a way where death does not mean the end of life for a person (28.3\%): people will rise from the dead with a body and soul $-2.5 \%$, only souls will live after death $-25.8 \%$. In this case it is also important to add that explicit disbelief (no faith) in the afterlife was only declared by one third of these young people (30.8\%) - a great percentage of them were not able to state clearly their opinion about the analysed question (40.8\%).

As far as faith in reincarnation is concerned, (which is unknown to Christianity which is the religion of the majority in Slovakia), it is interesting to see that its indicator was quite high. It was revealed that more than one third of the youth without religious affiliation declared their faith in reincarnation of souls $(34.2 \%)$ : definitely believe $-9.2 \%$, believe somewhat $-25.0 \%$. In this case we can also say that explicit faith in reincarnation was declared by only two fifths of these young people $(42.5 \%)$ - quite a large percentage of them marked the answer 'it's difficult to say' $(23.3 \%)$. When we reflect on the following empirical data it seems that the phenomenon of faith without religious affiliation within the Slovak religious environment can have, to a certain extent, some parallels with the acceptance of specific truths of the faith among non-Christian religions, for example Eastern ones.

Finally, one might formulate a question as to what the character of these researched young people's relationship to God is. On the basis of the acquired empirical results, we can say that approximately one quarter of them declared a more or less positive relationship to some supernatural reality (26.7\%). I know that God really exists and I have no doubts about it $-4.2 \%$; although I have some doubts, I feel that I believe in God -3.3\%; I sometimes feel I believe in God and sometimes I feel I do not - 2.5\%; I do not believe 
in a personal God but in some superior being $-16.7 \%$. Other respondents presented an agnostic (I do not know if God exists and I do not think we can find it out - 20.8\%) or an atheist attitude (I do not believe in God $-41.7 \%$ ), or were not able to provide a definite answer $(10.8 \%)$.

In the same way as in the case of practising of religious acts, in the case of acceptance of religious doctrine the phenomenon of faith without religious affiliation could also refer to about one fifth or one quarter of the youth involved in this research that do not identify with any specific religion and at the same time declares a faith in God or in the afterlife. In the case of faith in reincarnation (further incarnation of souls), the empirical indicators were even slightly higher, which shows quite a significant degree of sympathy among young people without religious affiliation with some Eastern religions, the truths of the faith or with their spirituality.

\section{Religious knowledge}

Among the basic parameters of religiousness, one can also find religious knowledge which is closely connected to a specific religion. Due to the fact that young people in Slovakia live in a predominantly Christian environment, I asked them, for example, about their knowledge of the Persons of the Holy Trinity, the Evangelists or the sacraments. It was demonstrated that almost one third of the youth without religious affiliation was able to name correctly all the Persons of the Holy Trinity: the Father, the Son and the Holy Spirit (30.0\%). We can also add to this several people involved in the survey who were able to name at least some Divine Persons (2.5\%) - more often the Father and the Son, more rarely the Holy Spirit.

The second important indicator of religious knowledge in the Christian context is the ability to remember the names of the Evangelists. On the basis of reported empirical data, we claim that almost one tenth of the young people without religious affiliation could correctly name all four Evangelists: Matthew, Mark, Luke and John (8.3\%). Several people involved in this survey who were able to name at least some of them (1.7\%), most often Mark, Luke and John, more rarely Matthew, can also be added to this figure. It is apparent that religious knowledge does not necessarily have to be an expression of religious participation and therefore it is difficult to say what percentage of the youth involved in this research represent the phenomenon of faith without religious affiliation in the case of the intellectual scope of religiousness.

\section{Religious experience}

Speaking of religious experience that can be categorized as a less official or a less formal expression of religious participation, we will present empirical data communicating the values which give meaning to human life, a feeling of closeness to God and a belief that 
God helps in times of difficulties. It can be said overall that nearly one tenth of the youth without religious affiliation find the meaning of life in religious faith (7.5\%): only faith $-0.8 \%$, not only faith but other values as well $-6.7 \%$. In order to have a more complete understanding, it is important to state that the explicit negation of the meaningful role of religious faith in their lives was declared by only two thirds of these young people (68.3\%) - quite a large percentage of them marked the answer 'it's difficult to say' (24.2\%). Other values in which youth find the meaning of life were mainly: me and my life, family and friends.

In order to enrich our sociological knowledge, I quote some specific statements: "In my life" ( a school-girl in Poprad); "In reaching my life goals" (a school-boy in Tvrdošín); "In everyday life, in the things happening around and in the people who are here for me as well as I am for them" (a boy from a school in Ružomberok); "To get to know myself" (a boy from a school in Poprad); "In the people that I love and spend a lot of time with, for example, instead of singing in church" (a boy from a school in Liptovský Mikuláś); "In reality happening in a real time and within me" (a school-boy from Dolný Kubín); "In life, family, friendship, marriage" (a boy from a school in Poprad); "Nature, everything around us, what we can enjoy every day" (a boy from a school in Tvrdošín); "I have my own goal that I try to reach" (a school-boy in Levoča); "In happiness and in the people around me" (a boy from a school in Poprad); "In real life, destiny" (a boy from a school in Ružomberok); "In my family, health, friends, love, education..." (a school-girl in Poprad); "In family, friends" (a girl from a school in Liptovský Mikuláš); "In my abilities and ambitions" (a boy from a school in Poprad); "I believe in myself" (a school-boy in Tvrdošín).

Another important indicator of religious experience is the feeling of God's closeness which does not impact only those who belong to various religions but also people without religious affiliation. On the basis of the acquired empirical results, one can say that equally almost one tenth of the young people without religious affiliation confirmed the experience of something which can be called a feeling of God's closeness in their lives (7.5\%). It is also important to point out that the explicit negation of experiencing the feeling of God's closeness was declared by only four fifths of these young people (80.8\%) - a certain percentage of them did not have a definite answer to this question (12.5\%). The situations where the youth experienced the closeness of God included: problems and help in overcoming them, nature and prayer. In order to expand further our sociological knowledge, I also include two specific statements: "Saving of life" (a boy from a school in Poprad); "It was not God, it was some superior authority, my chakras contained some curse" (a girl from a school in Poprad).

Finally, we can present empirical data related to the belief that God helps in difficult life situations. It is apparent that approximately one tenth of the youth without religious affiliation were convinced of the fact that we can count on God's help in hard times (10.0\%): definitely yes $-3.3 \%$, perhaps yes $-6.7 \%$. Similarly, in this case, it can be said that the explicit negation of the belief that God helps in hardships was declared by only three quarters of these young people $(75.8 \%)$ - a certain percentage of them marked the answer 
"it's difficult to say" (14.2\%). In the case of this presented parameter of religiousness, the phenomenon of faith without religious affiliation could represent about one tenth of the Slovak youth involved in this research that does not identify with any specific religion and at the same time links the meaning of life to faith, experiences a feeling of God's closeness or is convinced about God's help in difficult life situations.

\section{Religious community}

The term religious community or (community parameter of religiousness) is an integral part of the basic parameters of religiousness. It can be assumed that youth without religious affiliation will show (in the scope of this parameter) zero or only a minimal indicator of religiousness. This was in fact the case, because when asked a question about the character of their relationship to faith, these young people answered as follows: I believe and I adhere to the demands of the Church $-0.0 \%$; I believe in my own way $-14.2 \%$; I cannot say if I am a believer or not $-5.0 \%$; I am not a believer and I am not interested in these matters $-32.5 \%$; I am not a believer because the teachings of the Church are wrong $-27.5 \%$; something else $-11.7 \%$; it's difficult to say $-9.2 \%$. We are not certain as to what exactly is the focus of the answer "I believe in my own way" but in this case one can conclude that it points to a syncretic or private religiousness. When we connect, however, the second answer with some aspects of the third, sixth and the seventh answer, it is apparent that from approximately one fifth to one quarter of the youth being described declared a more or less positive relationship to faith - private or syncretic (not ecclesiastical). ${ }^{16}$

The next indicator speaks about the attitudes of youth without religious affiliation to priests, who are typically the leaders of religious communities. We were specifically interested in determining how much the young generation understands about their need for their existence. It was demonstrated that almost one quarter of these young people understand the presence of priests within society as useful $-23.3 \%$. In addition, it is important to point out that the explicit negation of their need for society was only declared by one half of this youth category $(44.2 \%)$ - quite a large percentage of them marked the answer 'it's difficult to say' (32.5\%). On the basis of the acquired empirical data, it can be argued that even though young people without religious affiliation do not feel the need for priests themselves, they still very much respect the fact that they are needed for many others. Although the indicator of religiousness among youth without religious affiliation, as far as the community parameter is concerned, was more or less zero, the indicator of private or synchronic religiousness represented approximately one fifth to one quarter of these young people.

\footnotetext{
${ }^{16}$ Concerning differences between public and private religions or religiousness, see: José Casanova, Religie publiczne w nowoczesnym świecie (Kraków: NOMOS, 2005), 83-124; Peter Beyer, Religia i globalizacja (Kraków: NOMOS, 2005), 127-138.
} 


\section{Acceptance of religious morality}

The last of the basic parameters of religiousness is the moral parameter which we can include among less official or less formal expressions of religious participation. In terms of its scope, sociologists of religion examine those moral values and norms that are more or less connected to religion, for example, attitudes to the commandments of the Decalogue, to certain selected norms of marital and family morality or selected types of behaviour. Overall, one can argue that only less than one tenth of the youth without religious affiliation viewed the first three commandments of the Decalogue (the so-called religious) to be definitely or somewhat binding, I. commandment $-6.7 \%$; II. commandment $-6.6 \%$; III. commandment $-6.6 \%$. As far as the other seven commandments of the Decalogue (the so-called moral) are concerned, the level of their acceptance by these young people was different, although overall it was significantly lower than in the case of examining the bulk of the youth involved in this research: IV. commandment $-75.0 \%$; V. commandment 68.3\%; VI. commandment - 44.2\%; VII. commandment - 61.7\%; VIII. commandment $-70.9 \%$; IX. commandment $-61.7 \%$; X. commandment $-52.5 \% .{ }^{17}$

Concerning the attitudes of the young people without religious affiliation towards some selected norms of marital and family morality, which are more or less emphasized by different religious organizations, we also witnessed various degrees of their acceptance. On the basis of the acquired empirical results, we were able to develop a scale - from the most frequent to the least commonly accepted moral norms: prohibition of marital infidelity $-70.0 \%$; prohibition of homosexuality $-35.8 \%$; prohibition of abortion $-12.5 \%$; prohibition of euthanasia $-10.8 \%$; prohibition of so-called free love $-5.8 \%$; prohibition of using contraception $-3.3 \%$; prohibition of a sex life prior to marriage $-1.7 \%$; prohibition of divorce $-1.7 \%$. One could argue that the third and the fourth of the above-mentioned norms meant almost no issue and the last four norms meant practically no moral issue. It is also true in this case that the indicators of acceptance for some selected marital and family norms were significantly lower than in the case of examining the bulk of the youth involved in this research. ${ }^{18}$

Finally, I would like to introduce further attitudes of young people without religious affiliation to various selected types of behaviour with a religious or moral character that are in the context of some religions, (e.g. Christianity which is the religion of the majority in Slovakia), understood as superstitions: horoscopes, sortilege, folk medicine and yoga. It was shown that these young people are somehow closer to the above-mentioned types of behaviour in their attitudes as the bulk of the youth involved in this research. Overall, we can form the following scale - from the most common to the least commonly accepted types of behaviour (linking answers such as "I practice it regularly", "I have tried it and

${ }^{17}$ Compare Ondrej Štefaňak, Religiozita mládeže v procese premien (Nitra: Univerzita Konštantína Filozofa v Nitre, 2009), 200-203.

${ }^{18}$ Compare Ondrej Štefaňak, Religiozita mládeže v procese premien (Nitra: Univerzita Konštantína Filozofa v Nitre, 2019), 211-215. 
it really works" and "I haven't tried it but there is something about it"): yoga $-54.2 \%$; horoscopes $-40.0 \%$; folk medicine $-32.6 \%$; sortilege $-25.9 \% .{ }^{19}$ It seems that on the basis of this presented empirical data the phenomenon of faith without religious affiliation is (in the Slovak religious context) connected with the acceptance of several practices from non-Christian religions (yoga) as well as with higher acceptance of certain superstitions (from the point of view of Christianity).

It is apparent that acceptance of the moral norms does not necessarily have to be an expression of religious participation and therefore it is hard to say what percentage of the youth in Slovakia being researched refers to the phenomenon of faith without affiliation in the case of the moral parameter of religiousness. If we consider religious norms exclusively (the first three commandments of the Decalogue) or perhaps even the norms which are quite significantly emphasized through various religious organizations (for example, prohibition of abortion and euthanasia), then this phenomenon, which has already been described, could represent around one tenth of these young people.

\section{Conclusion}

Following the presentation of various empirical data, it is apparent that the phenomenon of believing without belonging represents approximately from one fifth to one quarter of the youth in Slovakia (being researched) which do not identify with any religion, church or denominational organization - depending on specific parameters and indicators of religiousness. The highest indicators of the religious participation of these young people were reported in the case of acceptance of religious doctrine (faith in the afterlife or supernatural reality) and in the case of practising religious acts (at least rarely practising prayer). Lower indicators were reported in the case of religious experience (experience of the feeling of God's closeness or the belief that God helps in times of hardship), acceptance of religious morality (for example, the first three commandments of the Decalogue) and of course in the case of religious community (for example, the ecclesiastical orientation of religiousness). ${ }^{20}$

Overall, one can say (as far as general religiousness, relationship to God and to faith are mainly concerned) that the group of young people without religious affiliation consists of atheists -approximately two fifths of those examined, agnostics - approximately one third of those examined, believers with private or syncretic religiousness - approximately from one fifth to one quarter of those examined. In addition, it seems that the phenomenon of believing without belonging is (in the Slovak religious context) connected, to a certain degree, with acceptance of spirituality, various truths of the faith (e.g. reincarnation) or

\footnotetext{
${ }^{19}$ Compare Ondrej Štefaňak, Religiozita mládeže v procese premien (Nitra: Univerzita Konštantína Filozofa v Nitre, 2019), 223-224.

${ }^{20}$ Concerning the psychological and sociological mechanisms that have an influence on affiliation to various religious organizations, see: Rodney Stark and William Sims Bainbridge, Teoria religii (Kraków: NOMOS, 2007), 61-64.
} 
certain Eastern religious practices (e.g. yoga) as well as to higher acceptance of some superstitions (from the point of view of Christianity).

\section{Bibliography}

Beyer, Peter. Religia i globalizacja. Kraków: NOMOS, 2005.

Casanova, José. Religie publiczne w nowoczesnym świecie. Kraków: NOMOS, 2005.

Cipriani, Robert. Diffused Religion: Beyond Secularization. London: Palgrave Macmillan, 2017. https://doi. org/10.1177/0268580920906755

Davie, Grace. "Od obowiązku do konsumpcji: modele religijności w Europie Północnej na początku XXI w." Wokót wspótczesności, no. 2, (2004): 14-30.

Hervieu-Léger, Danièle. Religia jako pamięć. Kraków: NOMOS, 1999.

Mariański, Janusz. Emigracja z Kościota. Religijność mtodzieży polskiej w warunkach zmian spotecznych. Lublin: Wydawnictwo KUL, 2008.

Mariański, Janusz. Religia w spoteczeństwie ponowoczesnym. Warszawa: Oficyna Naukowa, 2010. https://doi. org/10.34839/wpt.2012.20.1.229-332

Piwowarski, Władysław. Socjologia religii. Lublin: Redakcja Wydawnictw KUL, 2000.

Spiegel, Egon. "Specter of Secularization. Against the Identification of Ecclesiastical Indifference and Religious Indifference." Lecture from the international scientific conference on the topic of: "Metamorphoses of Religion and Spirituality" (Warsaw - 23 May 2019).

Stark, Rodney, and Bainbridge, William Sims. Teoria religii. Kraków: NOMOS, 2007.

Štefaňak, Ondrej. “Katolícka mládež = katolícka viera?” In Porta fidei - Rok viery, edited by František Dlugoš, 165-196. Ružomberok: VERBUM, 2013.

Štefaňak, Ondrej. Religiozita mládeže v procese premien. Nitra: Univerzita Konštantína Filozofa v Nitre, 2019.

Wróbel, Szymon and Skonieczny, Krzysztof. "Introduction to Atheism." In Atheism Revisited, edited by Szymon Wróbel and Krzysztof Skonieczny, 1-14. Cham: Palgrave Macmillan, 2020. https://doi. org/10.1007/978-3-030-34368-2

Zulehner, Paul M. "Religia z wyboru jako dominująca forma społeczna.” In Socjologia religii. Antologia tekstów, edited by Władysław Piwowarski, 383-408. Kraków: NOMOS, 2003.

https://slovak.statistics.sk/wps/wcm/connect/54eb0cba-ec99-4549-8a33-5c86eead59c1/Tab_14_ Obyvatelstvo_SR_podla_nabozenskeho_vyznania_scitanie_2011_2001_1991.pdf?MOD=AJPERES\&C VID=knLHnky\&CVID=knLHnky\&CVID=knLHnky\&CVID=knLHnky, adapted 15 October 2020. 